\title{
O contexto ecumênico da Conferência de Puebla e suas contribuições para a unidade cristã
}

\section{The ecumenical context of the Puebla Conference and its contributions to Christian unity}

Elias Wolff

\section{Resumo}

Ao celebrarmos 40 anos da III Conferência Geral do episcopado católico latino-americano é importante verificar como essa Conferência inseriu o ecumenismo no conjunto das orientações pastorais da Igreja na América Latina. Iniciamos o nosso estudo apresentando importantes fatos ecumênicos da época, envolvendo as igrejas evangélicas, e os diálogos que a Igreja Católica realiza em âmbito mundial. Isso prepara o terreno para a compreensão da posição ecumênica do Conselho Episcopal Latino-Americano a partir da Conferência de Medellín e a sua continuidade na Conferência de Puebla. Destacamos o lugar do ecumenismo nas Conclusões da Conferência de Puebla, o vínculo entre diálogo e missão, a dimensão social do ecumenismo.

Palavras-chave: Conferência de Puebla. Ecumenismo. Igreja LatinoAmericana/Caribe.

\section{Abstract}

As we celebrate 40 years of the Third General Conference of the Latin American Catholic Episcopate, it is important to see how this Conference inserted the ecumenism into the whole pastoral orientation of the Church in Latin America. We began our study presenting important ecumenical facts 
of the time, involving the evangelical churches, and the dialogues that the Catholic Church carries out worldwide. This sets the stage for understanding the ecumenical position of the Latin American Episcopal Council from the Medellin Conference and its continuity at the Puebla Conference. We emphasize the place of ecumenism in the Conclusions of the Puebla Conference, the link between dialogue and mission, and the social dimension of ecumenism.

Keywords: Puebla Conference. Ecumenism. Latin American Church/ Caribbean.

\section{Introdução}

Com o Concílio Vaticano II, o ecumenismo foi assumido como elemento constitutivo da natureza, identidade e missão da igreja católica. ${ }^{1}$ A partir de então, o magistério católico exorta para que as conferências episcopais em todo o mundo encontrem o modo de aplicar as orientações conciliares sobre o ecumenismo, no contexto da recepção do Concílio como um todo. E isso acontece de três principais formas: criando estruturas para o diálogo no interior das próprias conferências, como delegados/as e comissões responsáveis pela promoção do ecumenismo; desenvolvendo a perspectiva/dimensão ecumênica dos projetos pastorais e da formação dos agentes de pastoral; estabelecendo relações concretas com as diferentes igrejas existentes no mesmo território.

Tal foi o que aconteceu com muitas conferências episcopais em diversos países da América Latina. No Brasil, por exemplo, a CNBB elaborou em 1966 o Plano Pastoral de Conjunto estruturado em 6 Linhas pastorais, sendo a "Linha 5" a responsável por dinamizar a causa ecumênica. Em âmbito continental, em 1967 o CELAM criou o Departamento para o Ecumenismo. E a partir da Conferência de Medellín em 1968, o ecumenismo foi sempre contemplado nas discussões e nas Conclusões de suas Conferências Gerais.

A Conferência de Puebla exemplifica tal fato. Embora nas Conclusões da Conferência de Medellín o ecumenismo já tenha sido contemplado explicitamente, de modo transversal nos vários temas das Conclusões, Puebla é a primeira Conferência do episcopado latino-americano que lhe dedica uma seção especial, composta de 28 números. A partir de então, as demais Conferências

${ }^{1}$ O presente trabalho foi realizado com apoio da Coordenação de Aperfeiçoamento de Pessoal de Nível Superior - Brasil (CAPES) - Código de Financiamento 001. 
também dedicam um espaço próprio nas Conclusões para tratar do assunto, mas de forma mais reduzida: Santo Domingo (1992) o trata explicitamente em 20 números; ${ }^{2}$ e Aparecida (2007) em apenas 8 números. ${ }^{3}$

A compreensão das orientações ecumênicas nas Conclusões das Conferências Gerais não se resume em medir a quantidade de vezes que o tema aparece explicitamente, mas do lugar em que ele se situa nos documentos, do tom teológico-pastoral das afirmações ecumênicas, e da sua conexão com o conjunto do documento. Daqui se deduz a capacidade de incidência na organização e ação da igreja nos diferentes contextos. As Conclusões de Medellín, por exemplo, talvez sejam as que propõem o ecumenismo de forma mais incisiva, permeando todo o documento de modo que o ecumenismo configura o espírito das Conclusões. Isso se explicita por outro fator: a Conferência de Medellín talvez tenha sido, de todas, a que mais viveu concretamente a experiência ecumênica: pela presença e atuação dos Observadores das diferentes igrejas e organizações de igrejas; e pela prática da hospitalidade eucarística. Talvez esses fatores de algum modo intimidaram a causa ecumênica em Puebla. Nesta Conferência os Observadores não tiveram a mesma atuação que lhes foi possibilitada em Medellín; a maior parte dos números onde trata-se explicitamente sobre o ecumenismo se resume em repetir o Decreto Unitatis redintegratio, do Vaticano II; e não avança na recepção das conquistas alcançadas pelo movimento ecumênico até então. Contudo, importante é observar que a Conferência de Puebla manteve, implícita e explicitamente, a orientação ecumênica na ação evangelizadora da igreja católica latino-americana e caribenha. As dificuldades enfrentadas para tanto não a impediram de posicionar-se fielmente ao Evangelho onde Jesus ora pela unidade dos/as discípulos/as (Jo 17,21), ao Vaticano II e às exigências da igreja de nosso tempo. Dessa forma, a continuidade à Medellín faz com que Puebla impulsione significativas práticas ecumênicas nas igrejas locais em todo o continente. E tal posicionamento incentivou também a continuidade da orientação ecumênica nas Conferências posteriores, de Santo Domingo (1992) e Aparecida (2007), realizadas em tempos de maiores incertezas que as de Medellín e de Puebla para o movimento ecumênico no mundo e na América Latina.

Assim, fazer memória dos 40 anos da Conferência de Puebla, implica em recuperar e fortalecer as suas orientações ecumênicas no hoje da igreja nos diferentes países da América Latina e do Caribe.

\footnotetext{
${ }^{2}$ DSD 132-152.

${ }^{3}$ DAp 227-234.
} 


\section{O contexto ecumênico da Conferência de Puebla}

\subsection{As igrejas evangélicas}

A década de 70 do século $\mathrm{XX}$ foi um período de intensa atividade ecumênica. As igrejas integradas no Conselho Mundial de Igrejas assumem a agenda do Conselho e também realizam agendas ecumênicas próprias em suas regiões. Dos eventos ecumênicos com significativa relevância no período destaca-se a V Assembleia do Conselho Mundial de Igrejas (CMI), realizada de 25 de novembro a 10 de dezembro em Nairóbi em 1975, com o tema Jesus Cristo liberta e une. A Assembleia contou com representantes das 286 Igrejasmembros e 16 observadores da igreja católica. E é realizada num momento de corrida armamentista, violação dos direitos humanos em muitos países e uma crise energética mundial. Em Nairóbi, esses problemas são encarados de maneira direta com o tema da libertação e a opção de ações concretas, como o Programa de luta contra o racismo.

Vale destacar a $2^{\text {a }}$ Seção da Assembleia pela ênfase dada à expressão "comunidade conciliar", tomada de uma reunião de Fé e Constituição realizada em Salamanca sobre Os conceitos de unidade e modelos de união. "Comunidade conciliar" se opõe à proposta de "unidade orgânica" afirmada na III Assembleia do CMI (New Delhi, 1961). Com isso tenta-se descrever aspectos da vida da igreja indivisa em todos os níveis: de uma comunidade de diálogo entre confissões distintas, na qual se podem examinar questões ainda não resolvidas, como eucaristia, ministério, autoridade, confissões de fé. Sem dúvida, o conceito "comunidade conciliar" é a elaboração máxima da proposta que o CMI apresenta à consideração de todas as igrejas em seu caminho para a unidade visível.

As igrejas na América Latina também têm suas iniciativas ecumênicas. No ano de 1969, realizou-se a III Conferência Evangélica Latino-Americana, considerada um dos eventos ecumênicos mais sintonizados com a realidade do continente pela sua apurada sensibilidade social, impulsionando o desenvolvimento de uma cristologia autóctone, uma antropologia libertadora, uma eclesiologia e missiologia inseridas. ${ }^{4}$ Isso influenciou para que nos anos 70, a União Latino Americana de Juventudes Ecumênicas - ULAJE, afirmasse "a opção por uma teologia que considerasse a libertação sociopolítica dos povos

\footnotetext{
${ }^{4}$ COSTAS, O., Una nueva conciencia protestante, p. 56-57.
} 
do nosso continente como inseparável da redenção total que Cristo oferece". ${ }^{5}$ Assim, segmentos das igrejas evangélicas reelaboram a sua teologia, a sua espiritualidade e a sua ação missionária, integrando a profissão da fé com projetos de ação que tenham incidência política.

Na III CELA foi confirmada outra importante organização ecumênica, a Unidade Evangélica Latino Americana - UNELAM, como responsável pela continuidade da articulação das relações ecumênicas das igrejas evangélicas do continente até a criação do Conselho Latino Americano de Igrejas - CLAI, 1982. ${ }^{6}$ Nesse contexto, é importante tratar também da Fraternidade Teológica Latino-Americana - FLT, criada em 1970 na consulta feita em Cochabamba, Bolívia, ajudando as igrejas a terem uma base comum para a compreensão do Evangelho de modo contextualizado na realidade dos diferentes países da região. É missão da FTL aprofundar a cultura teológica e ao mesmo tempo darlhe um perfil vinculado com a realidade do continente. E isso em perspectiva ecumênica, pois é fundamental a unidade das igrejas, como afirmou Samuel Escobar na reunião que planejava a criação da FTL, para "escutar a voz do Espírito Santo para seu povo latino-americano". ${ }^{7}$ São fundamentais também nessa década as atividades de Igreja e Sociedade Latino-Americana - ISAL e sua sucessora a Associação Social Ecumênica Latino-Americana-ASEL, fundada em Costa Rica, em 1975. É um momento em que se destacam novos líderes do movimento ecumênico no norte do continente e também na zona andina, quando muitas igrejas nacionais estavam atuando na defesa dos direitos humanos, condenando suas violações e enfrentando com denúncias os governos ditatoriais do continente. Destaca-se, ainda, a ação da Comissão Evangélica Latino-Americana de Educação Cristã - CELADEC, criada em Lima (1962) com o objetivo de "proclamar e ensinar o Evangelho mediante a obra de educação cristã". ${ }^{8}$ Auxiliado pelo pedagogo Paulo Freire, em sua quinta Assembleia (1974), a CELADEC faz a opção pela educação popular, com o objetivo de tomar consciência da opressão existente. Educação

\footnotetext{
${ }^{5}$ MÍGUEZ, N., De Rosario a Oaxtepec, p. 123.

${ }^{6}$ A UNELAM vinha sendo formada desde 1963, quando foi realizada no Rio de Janeiro uma consulta sobre "Serviço e Ação Social Cristã na América Latina". Em 1964 formou-se em Montevidéu, uma Comissão Provisória para a Unidade Evangélica Latino Americana UNELAM, que foi constituída em 1965, na assembleia realizada em Campinas, Brasil. A missão da UNELAM primava a promoção da unidade entre as igrejas evangélicas da América Latina, com cerca de 300/400 organizações eclesiásticas separadas e 8 milhões de crentes protestantes.

${ }^{7}$ Citado por PLOU, D. S., Caminhos de Unidade, p. 82.

${ }^{8}$ PLOU, D. S., Caminhos de Unidade, p. 135.
} 
cristã e educação popular são compreendidas como um único processo de aprofundamento da fé que liberta também das amarras dos sistemas sociais de opressão.

Portanto, na década de 70 do século XX o movimento ecumênico do continente vivia um intenso dinamismo e criatividade, expressando um forte potencial transformador. Mas em meados dessa década, o avanço dos governos militares, a repressão política e o consequente êxodo de líderes proeminentes do movimento criaram uma situação de desorientação dos projetos ecumênicos. Conflitos sociais, políticos e econômicos em quase todos os países do continente, produziram crises no funcionamento dos Conselhos Nacionais de Igrejas. Em 1975, uma consulta por carta, que contou com a participação de 144 igrejas nacionais da América Latina e Caribe hispano, mostrou que a UNELAM havia cumprido a sua missão, sendo necessária a criação de outro organismo a nível continental para continuar a tarefa ecumênica (CLAI, em formação, 1981). Assim entre os dias 18 e 25 de novembro de 1978, realizouse a Assembleia de Igrejas Evangélicas em Oaxtepec, Morelos, México, a qual tratando da unidade afirmou:

- O estabelecimento da unidade no seio da família mais próxima, ou seja com os grupos evangélicos, sem deixar de buscar oportunidades de diálogo com a Igreja Católica Romana ou com as diversas igrejas ortodoxas.

- Afirmar a busca da unidade sobre bases mínimas de princípios doutrinais, porque se vê a necessidade de ter um marco de referência sobre o qual dirimir diferenças e trabalhar unidos no testemunho de Cristo.

- Manifestar a solidariedade das igrejas com o povo e suas aspirações, considerando que "o desígnio de Deus está inscrito em todos os seres humanos criados à sua imagem" e que é o Espírito de Deus "quem leva o povo à sua unidade". ${ }^{9}$

Não obstante as dificuldades, o movimento ecumênico evangélico persiste em seus objetivos de vincular os cristãos em projetos de ação social que possibilitem o testemunho comum do Evangelho. Crescia a consciência de que para viver em uma sociedade opressora que não avança na justiça, a igreja tem

${ }_{9}^{9}$ PLOU, D. S., Caminhos de Unidade, p. 159. 
que perguntar-se sobre o sentido da sua função profética, priorizando a defesa dos direitos humanos, a preocupação pelos povos nativos, a defesa do ambiente.

\subsection{A igreja católica latino-americana e o ecumenismo}

Nesse tempo a Igreja Católica vive sob o impulso do Concílio Vaticano II que a orienta para integrar-se nas iniciativas ecumênicas. E o faz realizando diálogos oficiais com diversas igrejas e organizações ecumênicas. Desses diálogos resultaram significativas Declarações comuns, documentos que expressam convergências e consensos em questões doutrinais. Destacamos sete deles, todos publicados no vol. I do Enchiridion Oecumenicum:

1) Diálogo católico-anglicano: Declaração de Windsor (1971) sobre a Doutrina da Eucaristia (1971) e o Esclarecimento de Salisbury (1979), ${ }^{10}$ Declaração de Cantuária sobre Ministério e Ordenação (1973) e o Esclarecimento de Salisbury, ${ }^{11}$ Declaração de Veneza sobre Autoridade na Igreja (1976) e o Esclarecimento de Windsor (1981); ${ }^{12}$ 2) Diálogo católicoluterano: O Evangelho e a Igreja (1972), ${ }^{13}$ A Ceia do Senhor (1978); ${ }^{14} 3$ ) Diálogo católico-metodista: Relatório de Denver (1971) tratando de diversos temas, como cristianismo no mundo contemporâneo, a espiritualidade, a família cristãa ${ }^{15}$ Relatório de Dublin (1976) tratando sobretudo do testemunho comum e a salvação hoje e a espiritualidade; ${ }^{16}$ 4) Diálogo católico-luteranoreformado: A teologia do matrimônio e os problemas dos matrimônios interconfessionais (1976); 5) Diálogo católico-pentecostal: Relatório da primeira fase do diálogo (1972-1976), tratando do objetivo e método do diálogo, além de temas teológicos diversos, como o batismo no Espírito Santo, a iniciação cristã, o dom do Espírito Santo, a Escritura, tradição e desenvolvimentos, o movimento carismático, o discernimento dos espíritos, oração e louvor; ${ }^{17}$ 6) Diálogo católico-reformados: conclui-se a primeira fase do diálogo (1970-1977) com o documento: A presença de Cristo na Igreja e no

\footnotetext{
${ }^{10} \mathrm{EO}, \mathrm{p} \cdot 10-25$.

${ }^{11}$ EO, p. 26-41.

${ }^{12}$ EO, p. 42-68.

${ }^{13}$ EO, p. 554-588.

${ }^{14}$ EO, p. 589-653.

${ }^{15}$ EO, p. 903-950.

${ }^{16} \mathrm{EO}, \mathrm{p} .951-991$.

${ }^{17}$ EO, p. 1075-1089.
} 
mundo (1977); ${ }^{18}$ 7) Diálogo Católico-Conselho Mundial de Igrejas: Terceiro Relatório (1971), tratando sobre a fé e culto das igrejas, missão e unidade, o laicato, os Conselhos de Igrejas, testemunho comum e proselitismo, catolicidade e apostolocidade; ${ }^{19}$ Quarto Relatório (1975), tratando dos fundamentos comuns, como o testemunho e o chamado à renovação, a unidade da igreja, o desenvolvimento e a paz, a semana de oração pela unidade dos cristãos. ${ }^{20}$

O período pós-conciliar apresentou uma densidade teológica e pastoral como nunca vista na igreja católica do continente latino americano. O projeto de aggiornamento proposto pelo Vaticano II possibilitou aos teólogos católicos da América Latina uma reflexão marcadamente original, caracterizando-se pela aproximação da reflexão da fé com a realidade local. ${ }^{21}$ Isso significou o abandono do comportamento de importação do saber da fé, produzindo um conhecimento caracterizado pela incorporação das características próprias do cristianismo latino americano. Nesse horizonte social é que se desenvolve a integração da igreja católica no diálogo ecumênico - e também inter-religioso - no continente. Segmentos do catolicismo percebem que o ecumenismo contribui para melhor responder aos desafios da realidade de empobrecimento e injustiça social dos povos latino-americanos. Na reflexão sobre a fé, assumese a lógica das maiorias que sofrem injustamente, sobretudo pelos regimes totalitários nos países do continente. O fator social e o político provocam as igrejas a se integrarem nos movimentos sociais que buscam a transformação de situações de injustiça. Os movimentos em busca de transformação social reclamam pelo compromisso das igrejas com uma pregação do Evangelho que se traduza em ações concretas por justiça e libertação social. Tais movimentos se fortalecem integrando os cristãos nos seus quadros, de modo que agentes de pastoral, padres, pastores e bispos assumem as causas dos movimentos de trabalhadores, grupos estudantis, sindicatos, etc., num esforço comum pela construção de uma nova sociedade. Desse fato, vai nascer na América Latina um "jeito" de ser igreja que protagoniza o "Povo de Deus" preconizado na

\footnotetext{
${ }^{18}$ EO, p. 1093-1139.

${ }^{19} \mathrm{EO}$, p. 366-432.

${ }^{20} \mathrm{EO}$, p. $433-450$.

${ }^{21}$ P. F. ANDRADE mostra que essa preocupação não se deu apenas depois da realização do Vaticano II, como se verifica no primeiro encontro de teólogos realizado em Petrópolis, em março de 1964, o que é considerado o ponto de partida de um trabalho de pesquisa teológica da problemática da igreja latino-americana: Novos paradigmas e teologia latino-americana, $\mathrm{p}$. 49-62.
} 
eclesiologia do Vaticano II, mas que na América Latina assume conotações específicas, caracterizando-se pela estreita vinculação entre igreja e sociedade, o que modela a "Igreja Popular" e/ou Comunidades Eclesiais de Base.

Mas o ecumenismo não é assumido apenas pelas circunstâncias sociais. Ele é, antes, uma convicção da consciência cristã e eclesial. É a partir do compromisso com o desejo de unidade que Cristo quer que as igrejas se integrem nas causas ecumênicas. Assim, o ecumenismo tem uma razão teológica antes que social. Esta razão é o que justifica as igrejas assumirem compromissos comuns tanto na busca da transformação social, quanto na superação das divergências teológico-doutrinais entre elas existentes. As duas dimensões do ecumenismo interagem na compreensão do mundo e da igreja que nele deve dar testemunho do Evangelho.

\subsection{O Conselho Episcopal Latino-Americano}

O Conselho Episcopal Latino-Americano - CELAM, criado no Rio de Janeiro em 1955, tem como finalidade articular os bispos da igreja católica no continente em torno a causas comuns. Para isso servem as suas Conferências Gerais, que se caracterizam como acontecimentos privilegiados, cujos ensinamentos possuem um valor magisterial ainda que sejam de natureza mais pastoral do que doutrinal. Por isso, ao propor o ecumenismo como algo a ser vivido pelas igrejas particulares, as Conferências Gerais do CELAM estão fazendo, ao mesmo tempo, uma orientação doutrinal e pastoral. Doutrinal porque observam as orientações do Concílio Vaticano II e mostram o ecumenismo como um jeito de viver o Evangelho; pastoral enquanto aplicação prática dessas orientações nos projetos de missão contextualizados na realidade latino-americana.

Em outros estudos já abordamos o ecumenismo nas Conclusões das Conferências Gerais do CELAM em Medellín, $1968^{22}$ e Aparecida, 2007..3 A IV Conferência Geral do CELAM, aconteceu num contexto social e religioso no qual, como vimos acima, igrejas cristãs do continente manifestam significativa abertura social integrando-se nos movimentos que incorporam a perspectiva libertadora na compreensão da fé, e buscam um novo modelo eclesial que se configura como Comunidades Eclesiais de Base. O elemento de convergência

${ }^{22}$ WOLFF, E., Medellín, o ponto de partida do ecumenismo na Igreja Católica na América Latina, p. 287-302.

${ }^{23}$ WOLFF, E., O diálogo na Igreja e a Igreja do diálogo no documento de Aparecida, p. 532-569. 
das igrejas é a "opção preferencial pelos pobres", que não obstante a tensão gerada, torna-se o horizonte que configura o universo ecumênico da região. Essa opção desafia todas as igrejas à comunhão na fé "a partir de um Corpus Christianum em desintegração". ${ }^{24}$ A partir de então, católicos e protestantes são convidados a unirem-se para responderem a esse apelo do Espírito Santo no cristianismo latino-americano, fazendo com que a pluralidade eclesial não seja obstáculo para o ministério diaconal aos mais necessitados, como manifestação da multiforme graça de Deus.

A Conferência de Puebla reflete as mudanças eclesiais e sociais ocorridas nos dez anos que se seguiram a Medellín, que em muito dificultaram para discutir o ecumenismo. Em alguns setores católicos havia perplexidade e até mesmo temor acerca das propostas de renovação da Igreja e do seu empenho ecumênico. Este era considerado, por boa parte do episcopado, como ameaçador à identidade católica e causador de instabilidade pastoral ou doutrinal que poderia fragilizar a fé dos cristãos católicos. ${ }^{25}$ Exemplo da indisposição ecumênica em Puebla é o fato de apenas três bispos se decidirem espontaneamente fazer parte da Comissão 17, que tratou do ecumenismo, exigindo a exortação do secretário da Assembleia para congregar outros bispos. ${ }^{26} \mathrm{~A}$ presença dos observadores não teve o mesmo impacto e o mesmo papel realizado em Medellín. Não obstante, Puebla dedicou uma seção especial para o ecumenismo. E temáticas centrais da Conferência, como a opção pelos pobres, as Comunidades Eclesiais de Base e as pastorais sociais, ganharam intensa dimensão ecumênica nos anos posteriores à Puebla.

$\mathrm{Na}$ Conferência de Puebla participaram 6 observadores não católicos, sendo eles: 1. Bispo Anglicano José Saucedo, Bispo de México, Centro e Sul América; 2. Pastor Dr. Bertoldo Weber, luterano da IECLB, São Leopoldo, RS, Brasil, Membro do grupo misto de trabalho entre a igreja Católica e a Federação Luterana; 3. Bispo Metodista Paulo Ayres Mattos, presidente do Conselho de Igrejas Evangélicas Metodistas da America Latina (CIEMAL), Rio de Janeiro, RJ, Brasil; 4. Dr. Paul Warszausky, Secretário do Congresso Judaico Latino americano, Buenos Aires, Argentina; 5. Mons. Antonio Chedraoui, Vigário Patriarcal Ortodoxo de Antioquia, Bispo no México, Venezuela e América Central; 6. Irmão Roger Schutz, Prior da Comunidade Ecumênica de Taizé, França, convidado fraterno.

\footnotetext{
${ }^{24}$ DIAS, Z. M., Puebla '79, p. 23.

${ }^{25}$ SANTANA, J., Ecumenismo e Libertação, p. 265.

${ }^{26}$ HYPÓLITO, A., Documento de Puebla, p. 61.
} 


\section{O lugar do ecumenismo nas Conclusões da Conferência}

O tema do ecumenismo é apresentado na terceira parte das Conclusões da Conferência de Puebla, que trata sobre "Evangelização na Igreja da América Latina: comunhão e participação". Em 4 capítulos os bispos apresentam: os centros de comunhão e participação - a família, as Comunidades Eclesiais de Base, a paróquia e a Igreja Particular (cap. I); os agentes de comunhão e participação - o clero, a vida consagrada, os leigos e a pastoral vocacional (cap. II); os meios para a comunhão e participação - a liturgia, o testemunho, a catequese, a educação e a comunicação social (cap. III); e o diálogo para a comunhão e participação (cap. IV) - o ecumenismo, o diálogo com as religiões e com os não crentes.

É importante observar que o diálogo é colocado num horizonte eclesiológico e pastoral que lhe configura como constitutivo da consciência eclesial e da sua missão. É ao tratar da comunhão na Igreja que os bispos afirmam o valor do diálogo. O diálogo ad intra e ad extra mostra que a Igreja não pode dedicar-se apenas à primeira dimensão da comunhão sob o risco de isolar-se das realidades que estão para além de si mesma e que de alguma forma lhe dizem respeito. Após considerar os elementos da comunhão interna ao catolicismo, os bispos entendem que a comunhão não se limita no seu interior. A Igreja de Cristo transcende as estruturas da igreja católica, ${ }^{27} \mathrm{e}$ há de se promover uma comunhão mais ampla, ecumênica, que possibilita aos cristãos de diferentes tradições eclesiais entenderem-se partícipes da única Igreja de Cristo. O ecumenismo é compreendido, assim, como um caminho para a realização da comunhão na Igreja de Cristo.

A partir de Puebla (1979) as Conferências do CELAM dedicam uma seção específica para a promoção do ecumenismo em seus documentos finais. E nas Conclusões de Puebla o ecumenismo ganha um espaço mais amplo que em Medellín. ${ }^{28}$ Os bispos fazem uma constatação da pluralidade eclesial e religiosa da América Latina, ${ }^{29}$ da realidade dos não-crentes, ${ }^{30}$ dos aspectos

\footnotetext{
${ }^{27}$ LG 8; UR 3.15; US 13.

${ }^{28}$ DP 868-896. O documento final dedica sete parágrafos à orientação explícita do ecumenismo, a saber: 108, 991, 1098, 1107, 1108, 1115, 1120, sem, contudo, ir muito além de Medellín. A terceira parte do capítulo IV, onde mais se trata da questão, praticamente se limita a repetir as orientações do Decreto sobre o Ecumenismo do Vaticano II, Unitatis Redintegratio.

${ }^{29}$ DP $871-874$.

${ }^{30}$ DP 875.
} 
positivos e negativos dessa realidade,${ }^{31}$ destacando como positivo: o interesse pelo ecumenismo, os trabalhos conjuntos sobre a Bíblia, a oração e a ação comum entre as igrejas. ${ }^{32}$ Como negativos destacam: as resistências em relação ao ecumenismo, o proselitismo e o fundamentalismo. ${ }^{33} \mathrm{E}$ apresentam critérios doutrinais e pastorais para a ação da Igreja, ${ }^{34}$ como o desenvolvimento da dimensão ecumênica da missão, ${ }^{35}$ a participação no movimento ecumênico ${ }^{36} \mathrm{e}$ a promoção dos direitos humanos. ${ }^{37}$ Frente aos desafios da realidade religiosa plural, incentivam uma postura de diálogo por "um intercâmbio com as manifestações religiosas e culturais que caracterizam nosso mundo pluralista de hoje... (com) um caráter de testemunho, no máximo respeito da pessoa e da identidade do interlocutor. O diálogo tem suas exigências de lealdade e integridade de ambas as partes". ${ }^{38}$ Reconhecem os bispos que a prática ecumênica é ainda "incipiente" ${ }^{39}$ e orientam um ecumenismo em sentido amplo, com prioridade para ações comuns a favor da promoção humana, a defesa dos direitos humanos e a construção da justiça e da paz. ${ }^{40}$

\section{Diálogo e missão}

Os bispos entendem ser um dever da Igreja promover o diálogo que visa a comunhão "buscando áreas de participação para o anúncio universal da salvação". ${ }^{41}$ Compreendem que há um vínculo estreito entre diálogo e missão, pois o diálogo "não se opõe à universalidade da proclamação do Evangelho, mas a complementa" ${ }^{42}$ É o próprio Evangelho que entra em relação de "fecundo intercâmbio com as manifestações religiosas e culturais" ${ }^{43}$ da atualidade. A compreensão de diálogo apresentada em Puebla é ampla, condiz

\footnotetext{
${ }^{31}$ DP $876-882$.

${ }^{32}$ DP 976.

${ }^{33}$ DP $877-878$.

${ }^{34}$ DP 883-896.

${ }^{35}$ DP 883.

${ }^{36}$ DP 884.

${ }^{37}$ DP 888.

${ }^{38} \mathrm{DP} 883$.

${ }^{39}$ DP 64.

${ }^{40}$ DP 876.

${ }^{41}$ DP 869.

${ }^{42}$ DP 883.

${ }^{43}$ DP 883.
} 
com a universalidade do Evangelho o qual é destinado a todas as realidades de todos os povos. Por isso o diálogo deve ser assumido "como perspectiva global do trabalho evangelizador, mais do que simples tarefas de setores". ${ }^{44}$ Esse diálogo tem o caráter de testemunho, respeito ao outro e lealdade às próprias convicções. ${ }^{45}$

De forma pedagógica, Puebla orienta para a importância de levar a sério a identidade do interlocutor, estabelecendo três âmbitos do diálogo: ecumênico, inter-religioso e cultural (com os não crentes).

\subsection{O ecumenismo}

Os bispos constatam que "cresceu entre nós o interesse pelo ecumenismo" ${ }^{46}$ o que se demonstrava pelo apreço e a promoção conjunta das Sagradas Escrituras, a oração comum, nos diversos grupos de reflexão interconfessionais, no trabalho conjunto pela justiça social, os Conselhos de Igrejas. ${ }^{47}$ Verificam, porém, que também existem resistências, desconfianças e mesmo ignorância em relação ao ecumenismo, muitas vezes motivadas por interesses proselitistas, o que constitui um "sério obstáculo para o verdadeiro ecumenismo" ${ }^{48}$ Na perspectiva do Vaticano II e como já haviam afirmado na Conferência de Medellín, assumem o ecumenismo como algo constitutivo da identidade da Igreja e da sua missão. Lembram os bispos que o ecumenismo nasceu "precisamente no âmbito da missão", pois "não se pode pregar um Cristo dividido". ${ }^{49} \mathrm{O}$ ecumenismo é, assim, uma forma privilegiada de favorecer para que todos os cristãos cumpram o mandato missionário que Cristo deixou: "Ide por todo o mundo e pregai o Evangelho a toda criatura" (Mc 16,15). Por isso recorrem ao Vaticano II para exortar todos os fiéis para que "participem diligentemente do trabalho ecumênico", ${ }^{50}$ promovendo "a restauração da unidade entre todos os cristãos". Dessa forma o ecumenismo possibilita um testemunho comum da fé cristã. ${ }^{51}$

\footnotetext{
${ }^{44}$ DP 896.

${ }^{45}$ DP 883.

${ }^{46}$ DP 877.

${ }^{47}$ DP 876.

${ }^{48}$ DP 877.

${ }^{49}$ DP 883.

${ }^{50}$ UR 4.

${ }^{51} \mathrm{DP} 884$.
} 
Nos aspectos práticos do diálogo ecumênico, Puebla destaca quatro elementos: 1) a importância de observar a "hierarquia das verdades" da doutrina católica em diálogo com a doutrina de outras Igrejas, e ao mesmo tempo fazer uma leitura contextualizada da doutrina católica, de modo a possibilitar "uma resposta válida aos planejamentos que vêm da situação concreta latino-americana". ${ }^{53}$ 2) A importância de promover a espiritualidade ecumênica, sobretudo a Semana de Oração pela Unidade Cristã.54 3) a formação adequada para os agentes de pastoral, possibilitando uma organização da prática ecumênica através de grupos de estudo e reflexão ou Comissões e Conselhos Interconfessionais; ${ }^{55} 4$ ) a importância de promover um ecumenismo prático, envolvendo as igrejas em projetos de cooperação ecumênica que visem a construção da justiça social.

\subsection{O diálogo inter-religioso}

O ecumenismo tem especificidades próprias enquanto diálogo entre os cristãos. Mas ele não acontece isolado do diálogo também com as diferentes religiões, que se distingue do diálogo ecumênico em seus sujeitos, natureza e objetivos. Com o diálogo inter-religioso não se busca o testemunho comum da fé, mas possibilitar que, a partir da fé de cada um, os membros das diferentes religiões realizem projetos de cooperação em função de um mundo melhor. Os bispos percebem a existência do pluralismo religioso no continente, identificam suas expressões no que chamam de "movimentos religiosos livres" nas diferentes "formas religiosas ou para-religiosas", ${ }^{57} \mathrm{com}$ especial atenção ao Judaísmo ${ }^{58}$ e ao Islamismo. ${ }^{59}$ Analisam o significado das diversas formas de crer no continente e os desafios que apresentam para a convivência com a fé cristã. Buscam analisar a realidade religiosa plural dentro do plano salvífico de Deus que quer salvar a todos (At 4,12; 1Tm 2,4) e por todos Cristo morreu (Lc 22,20; 1Cor 11,24; 15,4), recorrendo ao Vaticano II para afirmar que de al-

\footnotetext{
${ }^{52}$ UR 11.

${ }^{53} \mathrm{DP} 888$.

${ }^{54} \mathrm{DP} 890$.

${ }^{55}$ DP 890.

${ }^{56}$ DP 872.878.

${ }^{57}$ DP 874.881.

${ }^{58}$ DP 873.879.

${ }^{59}$ DP 873.880.
} 
guma forma conhecida unicamente por Deus "o Espírito Santo oferece a todos a possibilidade de serem associados ao mistério pascal (GS 22)". ${ }^{60}$

É louvável como Puebla apresenta os valores positivos que se manifestam no pluralismo religioso. Entende que os "movimentos religiosos livres" manifestam desejo de comunhão, participação e liturgia vivida; ${ }^{61}$ que no monoteísmo islâmico existe a busca do Absoluto e de respostas aos questionamentos existenciais, o que se constitui como "pontos de aproximação para um diálogo", ${ }^{62}$ e nas outras formas religiosas ou para-religiosas "vislumbra-se a proposta de respostas para as necessidades concretas do homem, um desejo de contato com o mundo transcendente e espiritual". ${ }^{63}$ Temos aqui elementos fundamentais para o diálogo: identificar o que constitui a identidade do outro, buscar compreender sua manifestação e valorizar o seu modo de ser. Mesmo entre tensões e divergências, o valor da alteridade religiosa precisa ser afirmada, ainda que não seja possível partilhar de seus elementos constitutivos. Os bispos expressam o entendimento de que a finalidade primeira do diálogo não consiste em querer negar ou mudar o que o outro é, mas compreendê-lo em seu modo de ser.

Desse modo, é possível estabelecer sintonias e convergências entre a fé cristã e alguns elementos doutrinais ou éticos que se manifestam no interior do pluralismo religioso do nosso tempo. Existe, por exemplo, o reconhecimento da busca do Absoluto e do mundo transcendente e espiritual pelas diversas formas religiosas, e que estas são tentativas de respostas aos questionamentos da existência humana e possibilitam a vida em comunhão. Com relação ao Judaísmo, Puebla recorda o ensino conciliar sobre "o vínculo com que o povo do Novo Testamento está espiritualmente unido à raça de Abraão", pelo que é preciso "fomentar e recomendar o mútuo reconhecimento e apreço", promovendo o "patrimônio comum" ${ }^{64}$ das duas religiões. Dessa forma, Puebla segue a orientação conciliar de reconhecer, conservar e fazer progredir os bens espirituais, morais e os valores socioculturais das diferentes religiões ${ }^{65}$ e com elas cooperar na construção da "fraternidade universal". ${ }^{66}$

\footnotetext{
${ }^{60}$ DP 886.

${ }^{61}$ DP 878. 891.

${ }^{62}$ DP 879.

${ }^{63} \mathrm{DP} 881$.

${ }^{64}$ NA 4.

${ }^{65}$ NA 2.

${ }^{66}$ NA 5.
} 
Contudo, em Puebla os bispos apontam também para dificuldades e desafios que o pluralismo religioso apresenta para o diálogo com a fé cristã. $\mathrm{Na}$ verdade, o documento usa um espaço maior para falar dos elementos negativos constatados no pluralismo religioso do que o espaço para apresentar o que ali existe de positivo. Primeiramente, nem todas as expressões religiosas são vistas positivamente. Entendem os bispos alguns movimentos religiosos como "tendências alienantes", que afastam do compromisso concreto com as pessoas e o seu meio; ${ }^{67}$ algumas se afirmam ecumênicas mas instrumentalizam politicamente o diálogo.$^{68}$ Eles lastimam que em meio aos novos movimentos religiosos livres, juntamente com os valores que se manifestam, também existam "os marcados proselitismos, o fundamentalismo bíblico e o literalismo estrito com relação às suas próprias doutrinas", ${ }^{69}$ fatores que obstaculizam um diálogo sereno e a prática da cooperação na ação social; que muitas formas religiosas indicam para a busca de um mundo transcendente e espiritual mas tornam esse mundo subordinado pragmaticamente aos anseios das pessoas. ${ }^{70}$

$\mathrm{O}$ fato de identificar elementos de negatividade no meio das diferentes expressões religiosas não significa que Puebla desconsidera o valor das religiões como tal. Mostra com isso a ambiguidade existente em todo ato humano, mesmo quando religioso, do qual nem mesmo o cristianismo e a Igreja estão imunes. E isso mostra, uma vez mais, a importância do diálogo entre as diferentes formas de crer, que pode ajudar as diferentes religiões a se corrigirem e se purificarem no testemunho da própria fé.

Importantes para isso são as orientações pastorais para o diálogo, nas quais os bispos apresentam como principais exigências: a simplicidade e a humildade "como condição para um diálogo religioso fecundo"; ${ }^{71}$ ter a promoção dos direitos humanos e a busca de uma sociedade justa e livre como principal objetivo ${ }^{72}$ conhecer a fundo as diversas expressões de fé, em seus valores e em suas ambiguidades, ${ }^{73}$ tendo claro "as distorções" que algumas delas podem ter na vivência da própria fé cristã. ${ }^{74}$ Particularmente com os

\footnotetext{
${ }^{67}$ DP 877.

${ }^{68} \mathrm{DP} 877$.

${ }^{69}$ DP 878.

${ }^{70} \mathrm{DP} 881$.

${ }^{71}$ DP 887.

72 DP 888.

${ }^{73}$ DP 891.

${ }^{74}$ DP 893.
} 
judeus, orienta-se para o diálogo conforme o documento "Orientações e Sugestões para a aplicação da Declaração Nostra Aetate n. 4 ".75

\subsection{O diálogo com os não crentes}

Chama a atenção dos bispos em Puebla o fato que na América Latina "cresce o número dos que nem se preocupam com o fato religioso, ao menos na vida prática" ${ }^{76} \mathrm{~A}$ "não-crença" é entendida como "realidades muito diversas" que se manifesta desde pela recusa do divino até "por deformações da ideia de Deus e da religião". ${ }^{77}$ A compreensão dessa realidade é vista negativamente em suas causas, como "objetivações do pecado" presente nos elementos sociais, econômicos, políticos e ideológicos, e como "ambivalências" na busca da verdade e na promoção da liberdade. ${ }^{78}$ Trata-se de uma visão fortemente negativa não apenas da atitude de não crer, como também do meio no qual essa atitude é gerada, tal como os humanismos que, ao gerar o ateísmo, "obstaculizam o desenvolvimento integral da pessoa". ${ }^{79}$

É de se perguntar como uma pessoa não crente se sente ao ler tais expressões. A impressão que se tem é que para os bispos, o ato de não crer conduz necessariamente à frustração dos propósitos de felicidade e, consequentemente, ao fracasso existencial. É provável que muitos se sintam incomodados com tal leitura. E, no final dos anos 70, tal realidade era ainda menor do que se verifica atualmente. A igreja sempre teve dificuldades para dialogar com tal fato, o que levou a condenações e exclusões ao longo da história. Observa-se nisso uma grande dificuldade de diálogo com a cultura na qual o ateísmo é gerado e se manifesta. Naturalmente, os bispos não podem concordar com elementos socioculturais que contradizem ou negam a existência de um Deus. Constatam com razão que "a não-crença constitui uma interpelação e um desafio à fidelidade e autenticidade dos crentes e da Igreja (GS 19)" ${ }^{80}$ Contudo, também não podem impor suas convicções de fé como condutores da vida da sociedade. Urge afirmar o princípio da liberdade tal como ensina a Declaração Dignitatis

\footnotetext{
${ }^{75}$ DP 891. CONSELHO PONTIFÍCIO PARA A PROMOÇÃO DA UNIDADE DOS CRISTÃOS, Orientações e Sugestões para a aplicação da Declaração Nostra Aetate, n. 4.

${ }^{76}$ DP 875.

${ }^{77} \mathrm{DP} 875$.

${ }^{78}$ DP 882.

${ }^{79} \mathrm{DP} 882$.

${ }^{80}$ DP 886.
} 
Humanae ao apresentá-la como "estar livres de coação" de modo que "em matéria religiosa ninguém seja forçado a agir contra a própria consciência". ${ }^{82}$ Toda pessoa é livre para crer, mudar de crença e também deixar de crer. E isso os bispos compreendem ao afirmarem "não existindo fé pessoal que não seja livre". ${ }^{83}$ Mas há uma espécie de ressentimento e resistência em relação à nãocrença, uma postura mais de tolerância do que de liberdade propriamente dita. Não obstante, Puebla propõe o diálogo com os não crentes, buscando deles aproximar-se "com o maior respeito por sua liberdade pessoal, e procurando compreender suas motivações e razões" ${ }^{84}$ Acertam os bispos ao proporem uma "presença mais decidida" da Igreja ali onde se originam as vivências culturais e os "novos protagonismos", o que exige uma "pastoral orgânica da cultura" ${ }^{85}$ Tal fato permitirá melhor compreensão da realidade da não crença em nossos dias e a colaboração entre crentes e não crentes para um mundo melhor. ${ }^{86}$

\section{Destaques da orientação ecumênica em Puebla}

\subsection{A visão pastoral da sociedade}

No início do nosso estudo analisamos iniciativas ecumênicas da década de 70. É importante agora verificar em que medida e de que forma essas iniciativas podem ter encontrado algum eco na Conferência de Puebla. Talvez os bispos ali reunidos não acompanhassem o desenvolvimento da maioria dos acontecimentos ecumênicos, até mesmo porque em grande parte eram promovidos por organizações ecumênicas do meio protestante. Mas verifica-se nas Conclusões de Puebla uma significativa convergência social e pastoral com iniciativas ecumênicas protestantes. Atividades de ISAL, ASEL da UNELAM e ULAJE, entre outros, mostram um ecumenismo social que expressa o profetismo das igrejas protestantes, incentivando o testemunho do Evangelho de forma crítica às situações de injustiça social sofrida pela maioria da população latino-americana. Isso tem amplo consenso com o que os bispos propõem ao expressarem uma "preocupação preferencial em promover

\footnotetext{
${ }^{81} \mathrm{DH} 2$.

${ }^{82} \mathrm{DH} 2$.

${ }^{83}$ DP 886.

${ }^{84}$ DP 886.

${ }^{85}$ DP 894.

${ }^{86}$ DP 895.
} 
e defender os direitos dos pobres, marginalizados e oprimidos" ${ }^{87}$ E querem fazê-lo ecumenicamente: "com nossos irmãos que professam a mesma fé em Cristo, embora não pertençam à mesma Igreja Católica, esperamos unir os esforços, preparando constantes e progressivas convergências que apressem a chegada do Reino de Deus". ${ }^{88}$ É possível estabelecer sintonia da visão pastoral do contexto sociocultural que os bispos possuem ${ }^{89}$ com o que as igrejas evangélicas propõem na dimensão social do ecumenismo. Nesse contexto, as igrejas lançam um olhar comum para a realidade dos povos latino-americanos e identificam situações de injustiça que as interpelam. Em Puebla os bispos identificam os rostos sofredores de índios, camponeses, operários, moradores das periferias, desempregados, jovens, crianças e idosos ${ }^{90} \mathrm{e}$ compartilham das suas angústias. Fazem a "opção preferencial pelos pobres"91 e pelos jovens. ${ }^{92}$ Isso tem uma profunda dimensão ecumênica. É de se lastimar porque na América Latina a ação social da igreja não se desenvolve ecumenicamente como poderia acontecer. As convergências e os consensos que se manifestam na compreensão da realidade social e do papel da igreja nesse meio, constroem a base para que as igrejas atuem juntas em projetos que visam a transformação social que possibilita vida justa e digna para todos os povos do continente.

\subsection{Um modelo concreto de igreja na América Latina}

Outro destaque na Conferência de Puebla é a compreensão e organização da igreja num jeito latino-americano próprio, que na perspectiva conciliar do Povo de Deus assume o profetismo, a diaconia e a martyria. A razão de ser da igreja é o Reino da vida plena e abundante para todas as pessoas, e Deus o realiza em Cristo (Jo 10,10). A compreensão do Reino não é teórica, ele é identificado concretamente na prática do seguimento e do discipulado de Cristo: "dei-vos o exemplo para que façais..." (Jo 13,15). Isso em perspectiva libertadora, de modo que a missão da igreja consiste em anunciar o Reino da libertação da vida, para que ela seja plenamente e abundantemente vivida. Afinal, "foi para a liberdade que Cristo nos libertou" (G1 5,1).

\footnotetext{
${ }^{87}$ DP 977.

${ }^{88}$ DP 1013.

${ }^{89}$ DP 7-39.

${ }^{90}$ DP 20.

${ }^{91}$ DP 897-930.

92 DP 931-966.
} 
Essa igreja ganha um modelo próprio nas Comunidades Eclesiais de Base, como o espaço privilegiado para "inter-relação pessoal, aceitação da Palavra de Deus, revisão de vida e reflexão sobre a realidade à luz do Evangelho". ${ }^{93}$ Desenvolve-se a eclesiologia do Povo de Deus sustentada no sacerdócio comum dos fiéis - o clero e a hierarquia são vistos como integrantes do Povo de Deus e a partir da concepção da Igreja Povo. Outro elemento significativo é a centralidade da Palavra, que ouvida e meditada semanalmente é praticamente o que sustenta a vida de fé das comunidades que raramente possuem a Eucaristia. Um terceiro elemento é o fato de as comunidades eclesiais estarem na base da sociedade e serem formadas pelas bases sociais, o que favorece a contextualização da fé. As CEBs se difundem nos anos 70 principalmente pelas periferias das cidades e no meio rural.

Não é difícil verificar o alcance ecumênico da proposta eclesiológica das CEBs. A eclesiologia do Povo de Deus, o sacerdócio comum dos fiéis, a centralidade da Palavra e a inserção social as aproximam da eclesiologia evangélica. Naturalmente, as CEBs não se resumem a esses elementos, elas têm o ministério ordenado, os demais sacramentos e todo o conjunto doutrinal da igreja católica como constitutivo da identidade eclesial. Contudo, os quatro elementos acenados se expressam de forma mais explícita no cotidiano da vida das CEBs, de modo que por eles se estabelece um diálogo mais direto com a eclesiologia evangélica. Além disso, não poucas comunidades evangélicas adotaram o modelo das CEBs, o que favoreceu ainda mais para o diálogo e a cooperação na missão. Então, nesse período em muitas regiões da América Latina, católicos e evangélicos se fortalecem mutuamente no compromisso com a vida concreta das pessoas, da família, do bairro, da comunidade eclesial e da sociedade como um todo, num testemunho comum do Evangelho que creem e pregam.

\subsection{A missão}

A Conferência de Puebla teve o tema da evangelização como foco central. Buscou identificar os desafios e as possibilidades para a missão da Igreja na América Latina e no Caribe, aprofundar a compreensão do conteúdo da evangelização e do ato de evangelizar, promovendo a comunhão e a participa-

${ }^{93}$ DP 477. 
ção. O que se quer com a evangelização é "a proclamação integral da verdade sobre Jesus Cristo, sobre a missão da Igreja, sobre a natureza, a dignidade e o destino do homem". ${ }^{94}$

Essa tarefa exige da igreja opções concretas que possibilitem a proclamação do Evangelho de modo a responder aos desafios e aos questionamentos dos povos do continente. Puebla dá continuidade às opções feitas na Conferência de Medellín, destacando a opção pelas juventudes, pelos pobres e pelas Comunidades Eclesiais de Base como caminhos privilegiados da missão. Os bispos percebem que nem sempre o modo de evangelizar condiz com a realidade em que vivemos. E na "Mensagem aos Povos da América Latina" eles perguntam: "vivemos, de fato, o Evangelho de Jesus Cristo em nosso Continente?". ${ }^{55}$ Nisso os bispos reconhecem "falhas e limitações", pelo que pedem perdão "a Deus e a nossos irmãos na fé e na humanidade". ${ }^{96}$

Nesse pedido de perdão os bispos mostram que o compromisso da missão os coloca em relação com todos os povos, cristãos e não cristãos, a quem se estende o mea culpa. Essa consciência de vínculos universais expressa a postura relacional, dialógica, comunional da missão em Puebla. A grandiosidade da missão exige a cooperação das forças ad intra e ad extra ecclesia. Nenhuma igreja sozinha tem condições de realizar tal tarefa.

Aparece aqui a ecumenicidade como constitutivo da missão. Puebla tem consciência que a razão de ser da igreja é evangelizar. E podemos estabelecer um vínculo dessa consciência com a motivação original no movimento ecumênico latino-americano: a preocupação que participantes do Congresso de Edimburgo (1910) tinham para com a evangelização na América Latina. Desse modo, a pergunta se o Evangelho é, de fato, vivido no continente ganha dimensão ecumênica, inter-religiosa e intercultural, como explicitam os bispos: "Esta interpelação dirigimos não somente aos cristãos, mas também a todos os homens que não partilham de nossa fé". Dessa forma, as Conclusões de Puebla expressam a resposta que os bispos dão à pergunta por eles feita. Mas é importante ouvir como outras igrejas também a respondem. O questionamento é um apelo a uma compreensão ecumênica da missão em nosso meio.

\footnotetext{
${ }^{94}$ Documento de Puebla - Introdução Geral, p. 11.

${ }^{95}$ Documento de Puebla - Introdução Geral, p. 8.

${ }^{96}$ Documento de Puebla - Introdução Geral, p. 8.
} 


\subsection{O ensino ecumênico}

Puebla aponta os avanços do ecumenismo - a promoção e o apreço da Sagrada Escritura, a oração comum, o surgimento de grupos de reflexão interconfessionais, a cooperação na promoção humana, a defesa dos direitos humanos, a construção da justiça e da paz; ${ }^{97}$ e também obstáculos, como a "ignorância ou desconfiança" com relação ao ecumenismo, as "tendências alienantes em alguns movimentos religiosos, que apartam o homem do seu compromisso para com o ecumenismo ou instrumentalizações políticas que desvirtuam o caráter do diálogo". ${ }^{98}$ É importante observar que Puebla dá pistas pastorais concretas para que nas comunidades dos cristãos católicos o diálogo seja uma realidade cotidiana. ${ }^{99} \mathrm{E}$ isso inclui o ensino ecumênico como formação para o diálogo, a qual orientam os bispos para priorizar, entre outros elementos, a criação de atitudes de simplicidade e de humildade em relação às diferentes igrejas; a promoção dos direitos humanos (e pode-se acrescentar hoje, da criação); a compreensão da hierarquia das verdades na doutrina católica; a participação nas Semanas de Oração pela Unidade Cristã; conhecer a fundo o pluralismo religioso atual. Essas orientações, entre outras, possibilitam uma verdadeira capacitação para o diálogo dos agentes de pastoral católicos, de modo a poderem "considerar a dimensão ecumênica e a abertura ao diálogo com o mundo não-cristão e da não-crença, como perspectiva global do trabalho evangelizador, mais do que simples tarefa de setores". ${ }^{100}$

Assim, observa-se que as Conclusões de Puebla estão em sintonia com as orientações do Magistério universal que orientam para a formação ecumênica de quem trabalha na evangelização. ${ }^{101} \mathrm{De}$ fato, não há prática consistente de diálogo sem a formação de uma adequada mentalidade e de um espírito dialógico, de modo que o diálogo se torne atitude, modo de ser, que se expressa nas relações cotidianas. Isso é condição para que o diálogo ecumênico, e interreligioso, seja fecundo na geração de novas situações de paz, de justiça e de promoção da vida no mundo atual.

\footnotetext{
${ }^{97}$ DP 1107.

${ }^{98}$ DP 1108.

${ }^{99}$ DP 887-896.

${ }^{100}$ DP 896.

${ }^{101}$ UR 10. Também: CONSELHO PONTIFÍCIO PARA A PROMOÇÃO DA UNIDADE DOS CRISTÃOS, A dimensão ecumênica na formação dos que trabalham no ministério pastoral, n. 79.
} 


\section{Conclusão}

A Conferência de Puebla dá continuidade à opção ecumênica do Concílio Vaticano II, já assumida na Conferência de Medellín. O diferencial é o fato de colocar em destaque o tema nas suas Conclusões, enquanto em Medellín ele está disperso no documento final. Tal fato não significa, porém, avanços concretos na causa ecumênica proposta em Puebla. Na verdade, em Medellín os bispos foram mais propositivos na expressão da ecumenicidade da igreja e sua missão do que em Puebla. O clima eclesial de Medellín era mais favorável à busca da renovação eclesial proposta pelo Vaticano II. E isso influenciou positivamente na questão ecumênica, como mostra a atuação intensa dos observadores e a prática da hospitalidade eucarística. E foi exatamente em relação a esses fatores que a Conferência de Puebla se apresentou tímida. Os observadores não tiveram o mesmo espaço de atuação, a Conferência foi mais conduzida pelo Vaticano e nesse contexto sequer se cogitou a possibilidade de repetir o gesto da hospitalidade eucarística.

Contudo, o fato de orientar explicitamente a causa ecumênica, inclusive com uma seção específica para o ecumenismo no conjunto das Conclusões, é altamente positivo em Puebla. E o faz na proposta de uma igreja comunhão. Pedagogicamente explicita-se melhor a compreensão de ecumenismo, sua natureza, seus objetivos e as formas concretas da vivência ecumênica. Isso reforça a integração da causa ecumênica no conjunto das orientações da Conferência, como algo constitutivo da concepção da igreja e da sua missão na América Latina.

O desafio agora, é retomar o legado ecumênico da Conferência de Puebla atualizando-o no hoje da re-recepção do Vaticano II proposto pelo Papa Francisco. Isso implica inserir decididamente o ecumenismo nas iniciativas práticas nas bases das igrejas, pastorais e movimentos; na formação dos agentes de pastoral, na reflexão dos teólogos. E oferecer subsídios para o encontro das hierarquias das igrejas na busca da comunhão na fé e na colaboração na missão. É esse esforço que possibilitará sensíveis mudanças nas relações entre as igrejas do continente, em vista do testemunho comum do Evangelho que todas creem e proclamam, a favor da vida dos povos latino-americanos. 


\section{Referências bibliográficas}

ANDRADE, P. F. Novos paradigmas e teologia latino-americana. In: ANJOS, M. F. (Org.). Teologia e novos paradigmas. São Paulo: Soter / Loyola, 1996. p. 49-62.

CELAM. Conclusões da Conferência de Aparecida. São Paulo: Paulinas 2007.

CELAM. Documentos do Conselho Episcopal Latino-Americano CELAM: Rio, Medellín, Puebla, Santo Domingo. São Paulo: Paulus, 2004.

CERETI, G.; VOICU, S. J. (Org.). Enchiridion Oecumenicum. Documenti del dialogo teologico interconfessionale. Bologna: Editoriale Dehoniano, 1994. v.1.

CONCILIO VATICANO II. Constituição Dogmática Lumen Gentium sobre a Igreja. In: CONCILIO VATICANO II. Documentos do Concílio Vaticano II. São Paulo: Paulus, 2007. p. 101-194.

CONCILIO VATICANO II. Declaração Dignitatis Humanae sobre a liberdade religiosa. In: CONCILIO VATICANO II. Documentos do Concílio Vaticano II. São Paulo: Paulus, 2007. p. 411-428.

CONCILIO VATICANO II. Declaração Nostra Aetate sobre a Igreja e as religiões não-cristãos. In: CONCILIO VATICANO II. Documentos do Concílio Vaticano II. São Paulo: Paulus, 2007. p. 339-345.

CONCILIO VATICANO II. Decreto Unitatis Redintegratio sobre o ecumenismo. In: CONCILIO VATICANO II. Documentos do Concílio Vaticano II. São Paulo: Paulus, 2007. p. 215-239.

CONSELHO PONTIFÍCIO PARA A PROMOÇÃO DA UNIDADE DOS CRISTÃOS. A dimensão ecumênica na formação dos que trabalham no ministério pastoral. São Paulo: Paulinas, 1998.

CONSELHO PONTIFÍCIO PARA A PROMOÇÃO DA UNIDADE DOS CRISTÃ OS. Orientações e Sugestões para a aplicação da Declaração Nostra Aetate. Disponível em: <http://www.vatican.va/roman_curia/pontifical_ councils/chrstuni/relations-jews-docs/rc_pc_chrstuni_doc_19741201_nostraaetate_en.html >.Acesso em: 20 dez. 2018.

COSTAS, O. Una nueva conciencia protestante. Pastoralia, v.1, n.1, p. 56-57, 1978. 
DIAS, Z., M. Puebla'79: Una tentativa de contrarreforma? Impressiones de un protestante. In: BONINO, J. M. (Org.). Puebla y Oaxtepec. Una critica protestante y catolica. Buenos Aires: CUPSA / Tierra Nueva, 1980. p. 23-32. HYPÓLITO, A. Documento de Puebla: Contribuición para el ecumenismo?. In: BONINO, J. M. (Org.). Puebla y Oaxtepec. Una critica protestante y católica. Buenos Aires: CUPSA / Tierra Nueva, 1980. p. 61.

JOÃO PAULO II, PP. Carta Encíclica Ut Unum Sint. São Paulo: Paulinas, 1995.

MÍGUEZ, N. De Rosario a Oaxtepec: los movimientos ecuménicos y la búsqueda de la unidad Cristiana en América Latina. In: CLAI (em formação). Oaxtepec, 1978: Unidad y misión em América Latina. Quito: CLAI, 1978. p. $121-131$.

PLOU, D. S. Caminhos de Unidade. Itinerário do diálogo ecumênico na América Latina. São Leopoldo: Sinodal; Quito: CLAI, 2002.

SANTANA, J. Ecumenismo e Libertação. Petrópolis: Vozes, 1987.

WOLFF, E. Medellín, o ponto de partida do ecumenismo na Igreja Católica na América Latina. In: SOUZA, N.; SBARDELOTTI, E. (Orgs.). Medellín: memória, profecia e esperança na América Latina. Petrópolis: Vozes, 2018. p. 287-302.

WOLFF, E. O diálogo na Igreja e a Igreja do diálogo no documento de Aparecida. REB, v.268, n.71, p. 532-569, jul./set. 2008.

Elias Wolff

Doutor em Teologia pela Pontificia Università Gregoriana Docente do Programa de Pós-graduação em Teologia da Pontifícia Universidade Católica do Paraná Curitiba / PR - Brasil E-mail: elias.wolff@pucpr.br

Recebido: $23 / 01 / 19$

Aprovado: 10/05/19 